\title{
Survey of Free Market Principles for Encouraging Market: Participation of African American and the Economically Challenged
}

\author{
Amaechi N. Nwaokoro ${ }^{1}$ \\ ${ }^{1}$ College of Business, Albany State University, Albany, Georgia, USA \\ Correspondence: Amaechi N. Nwaokoro, College of Business, Albany State University, 504 College Drive, \\ Albany, Georgia 31705, USA. Tel: 229-430-4723. E-mail: amaechi.nwaokoro@asurams.edu
}

Received: April 13, 2016

Accepted: May 19, 2016

Online Published: December 18, 2016

doi:10.5539/ijef.v9n1p130

URL: http://dx.doi.org/10.5539/ijef.v9n1p130

\begin{abstract}
This study targets to challenge African American and other economically challenged to embrace free market principles to enhance their participation in the economy of Albany/Dougherty County, Georgia. With a market-based questionnaire, this study assess the understanding of these principles from among the students of Albany State University, the major educational institution in the county. Among other compelling actions, the responses provided on the survey highlight the need for effective education, increasing interest in taking market risks, elevation of access to capital, and fairer and inclusive society.
\end{abstract}

Keywords: poverty, inequality, partnership, financial instruments, accessible capital, market principles, free enterprise

\section{Introduction}

African American, in particular, has a substantially low business ownership in Albany/Dougherty County where African American has a majority status with $60.1 \%$, and the White and Hispanics make up $37.34 \%$ and $1.3 \%$ respectively of the county's population of 96,065 (Note 1). In this situation, one should expect substantial dimensions of ethnically related poverty and other inequalities where the majority tends to dependent on the white minority to have access to employment, justice and considerations, capital, and to other opportunities. If a representative of African Americans cannot economically stand out in this county, one would wonder how much they fare in other counties. If the low African American business ownership in this county is comparable to those of other counties in the U.S., then a significant discussion must come to bear on ethnic poverty.

Remotely located in Southwest Georgia where southern poverty is prevalent (Note 2), Albany/Dougherty County is income-stratified, non-macro economically harmonized, and is dualistically entrenched by race leading to East and West Albany. Impoverished East Albany is mostly inhabited by African Americans while the White live in the West Albany where African Americans conventionally own faith-based initiatives. The White and recent immigrants have the ownership of most of the small businesses in the East Albany. The county has a substantial economic inequality issues that seem to emanate mostly from an inadequate awareness of the principles of a free market economy. The inequality issues relate to the disparities from the economic and educational achievements, poverty, and unemployment that are prevailing in the county. These adversities tend to disproportionally characterize the ethnic minorities, African American in particular. Inequality issue can arise whereby the would-be-market participants of the African American ethnic group, cannot articulate the exposition of the free market principles and of the activities of the financial market. Income earned from the financial market augments the income from the labor market that most people apply to. Nationally, only $10 \%$ of African Americans owns stocks and bonds and only $18 \%$ of American Indians receives some kinds of incomes from financial investments, stocks, and property (Lui et al., 2006, pp. 77, 32).

Economic inequality issues could arise due to a limited education most especially from the African American community. Educational achievement is positively related to a non-discriminating wage rate and to other opportunities. As African American's educational achievements lag behind that of the White being minority in the county, the inequality issue will linger. With limited education, labor may not have favorable negotiations on the terms of labor contracts and will most likely be paid a wage rate that is lower than the value of the physical marginal product of labor. Given limited opportunities, a felon with a limited education may have to settle with any wage rate offered. A labor with a limited education or is unskilled is most likely to be a subject to 
employment shocks most especially where labor and capital are substitutable in the production process. The diverse economic inequalities tend to emanate mostly from a limited understanding of free market principles and from the lagging educational achievements in this remote county that is divided by segregation and discrimination. Due to increasing city vices, there is an exodus of white and middle class African Americans out of the county to the nearest rural counties and this leads to some market failure. All these inequalities lead to a substantial African American and White purchasing power disparity explained by a quotient (Note 3) of (0.545). This estimate shows that the average African American earns roughly fifty-five cents for every one dollar that the average White person earns. Very high unemployment rates characterize the Albany/Dougherty (Georgia Department of Labor, 2010).

The crucial roles of concepts, business partnership, financial institutions, entrepreneurship, and microfinance institutions in a market driven economy seem not to be understood. The ability to understand these market attributes would not only assist in the development of market human capital, they also enable individuals to self-select into the economic activities where they command the greatest comparative advantages. A latent African American market participation is explained by the group's limited understanding of the market specific traits and of entrepreneurship particularly (Lofstron \& Bates, 2007; and Ucbasaran et al., 2008). Adams-Cooper (2011) could not highlight African American business partnerships even in the predominantly African American neighborhood. Partnerships are highlighted mostly in non-profit and faith-based initiatives. Business partnership assists in amalgamating funds and other resources that is beyond the resources of an individual to underwrite the initial outlay of business formation. Some small scale partnerships among those with common interests could be the routes to introduce the economically challenged to economic markets. Understanding the roles of the various financial intermediaries in a market economy could assist the economically challenged to locate where there could be a consideration for some small scale capital formation.

It seems most effort is directed toward getting jobs. In the absence of job opportunities, effort seems inhibited and productive people could end up on program incomes. People tend to ignore or have not realize the important role of entrepreneurship in a price-driven economy for increasing their incomes and the incomes and opportunities of others. This market attribute needs to be highlighted for people to realize that there are various dimensions of market risks undertaken by entrepreneurs (risk takers) to effect increase in their incomes and those of others. Even the economically challenged could step out to undertake some calculated risks at some appropriate levels to enhance their expected market rewards. Another market factor that could place and sustain the economically challenged mostly in the market is the microfinance institutions. Besides making concessionary loans and advances, these institutions provide some specialized services that are not handled by the conventional financial intermediaries. These institutions are on record for alleviating poverty in South America, and in Southeast Asia (Khandker \& Shahidur, 2005; Morduch, 2002; Ahmed, Chowdhury, \& Bhuiya, 2001). These institutions can enhance microenterprise to encourage a shift to economic activities (Servon \& Bates, 1998).

Based on the perceived inability of the economically challenged, African Americans in particular, to apply adequately to a market economy, the objective of this study is to use market-based questionnaire to sample the articulation of the exposition of market principles by the would-be-market participants from among the students of Albany State University, the major educational institution in the county and to provide actions for alleviating the market inhibitions. Particularly, the study serves to ignite the latent commercial articulation of the ethnic African American majority, and of other economically challenged in Albany/Dougherty. College students would most likely be educationally-driven entrepreneurs that would have an impact on alleviating the economic and the other inequalities. The questionnaire items focus on the roles of price mechanism, business partnership, entrepreneurship, financial market, and skills acquisition and labor market. Both male and female students applied to the questionnaire.

From the overall responses, there was a failure in recognizing the general activities of a market economy. Cautiously speaking, the survey responses revealed specifically, the students' understandings of the crucial role of entrepreneurship and of profit motive as factors or principles in the economic markets. Compelling actions to address the failure of the performance on the survey items would include but not limited to the need for: effective education, increasing interest in taking market risks, elevating access to capital, and for fairer and inclusive society. The rest of this study is laid out as follows. Section two presents the literature review on the sources of poverty and economic inequalities, on the economic markets, and on the associated crucial factors and institutions. Respectively, sections three and four present the data and methodology, and the research findings and results. Section five handles the conclusion and direction for future study. 


\section{Literature Review}

The literature review will highlight the sources of poverty, the diversity of markets, and the roles of the market supportive institutions.

\subsection{Sources of Economic Inequalities in African American Community of Dougherty County, Georgia}

Many sources, including the environmental duality caused by segregation and discrimination, the carryovers from slavery, tend to perpetuate poverty and the other inequalities in Albany/Dougherty County. Lack of black entrepreneurship during the slavery tends to hinder the African Americans' contemporary perceptions of free market factors. At the end of slavery, without some capital, African Americans found themselves on marginal lands that lacks macroeconomic framework. Those in impoverished neighborhoods are more restricted from applying to American free enterprise system. It is even rare to have African American entrepreneurs even in the predominantly African American neighborhood where the new immigrants from Asia and white people commercially excel. Instead of having business diversity, African American's effort, when exercised, seems to be directed at creating businesses that are similar to the few petty ones already established. This non-market foresight leads to unhealthy competition. These adversities seem to be the foundation of African American dependency on White's employment and on subsistence activities that perpetuates poverty and the economic inequalities right from the beginning of the African Americans' freedom.

Poverty has been carried over from the colonial America in which only the freed were judged by the incidence of poverty. The poverty of the Blacks then was considered normal since those that were not free did not have the opportunity to use own labor to obtain their economic security. Those that were free and could not acquire economic security by their labor were seem as being morally flawed or morally bankrupt. With much human development in a post-industrial period, poverty is explained by cultural theories. Schiller (2008, p. 156) explains that:

"Most cultural theories of poverty assert that the poor lack sufficient desire and motivation to escape poverty. They allege that the goal of economic security is of lesser importance in the value matrix of the poor. Welfare mothers would rather have kids than jobs. Young men would rather "hustle" on the street corners than accept a regular job. An overriding focus on immediate gratification discourages family planning, the pursuit of education, or the accumulation of savings. Because they are trapped by this culture, the members of the underclass don't behave in ways that would help them escape from poverty."

Some of these characterizations may not be true, but the modern day African American poverty tends to reflect limited understanding of market principles, of the importance of market partnership, and of the crucial role of entrepreneurship in a market economy. In the face of resource scarcity, African American's economic engagements tend to be in a few non-diversified markets. Resource scarcity and limited educational achievements (Note 4) may have compelled some preference to self-select governmental programs and faith-based activities for income securities in a postindustrial era. Also preference tends to be dependence on white establishments for economic security. Perpetuated poverty might have led to some dependency on programs given the non-understanding as to how the market economy works. African American ethnic poverty and the inequalities faced may need to be visited with both striving market principles and substantial level of exogenous capital investment to economically uplift the economies of the restricted neighborhoods.

Poverty tends to perpetuate intergenerational poverty as children of programs dependent families may not be cognizant of how income and wealth can be earned from the economic markets. Though the sources of the African American's economic adversities have been mitigated in both post war eras by legislation, by establishment of HBCU schools, and by encouraging, an increase of African American employment participation, most African Americans may not be aware of the activities in the various markets that make up the market economy. Particularly, they have not fully realized the importance of financial market where incomes can be earned to augment labor market incomes that they are used to. The undiversified nature of the educational institutions in the county tend to limit educational interaction and shared values only within racial groups.

Besides being remotely located, the county is dualistically divided by the Flint River and this situation leads to East and West Albany. These two constraints tend to limit the citizens' market participation and therefore leads to poverty. Most employment, financial, and other opportunities are apparent in the West and North sides of the county. The East is populated mostly by African Americans with $91 \%$ of the population and a poverty rate of $45 \%$ (Farr \& Slade, 2008; Hoynes et al., 2006). An interaction between enlarged poverty and limited education would perpetuate generational poverty and economic inequalities that would grossly affect the benefits of comparative advantage and specialization (Bagi, 2008). The economically disadvantaged in the restricted environments that are being challenged by economic incentives would either drive or are driven to the opportunity areas. Those 
who do not have the luxury of having work transportation are therefore trapped in the restricted and impoverished areas. Due to the remoteness of the county, it takes approximately three and half, and two and half driving hours respectively to access employment and other opportunities in the nearest industrial cities of Atlanta Georgia and Tallahassee Florida. Georgia's portion of the Interstate 75 constructed in mid 1970s is said to have taken business opportunities from the county's traditional business areas (Farr \& Slade, 2008).

White and rich African Americans are leaving the county. Businesses are also relocating out of the county. Firestone, the US. Naval Air Station and Merck Pharmaceuticals have left. These movements that are mostly from the City of Albany tend to be responses to the expected increasing city crimes, to declining educational achievements from the public schools system, and to declining business opportunities. Involuntary unemployment and poverty are the outcomes of these movements (Schmitt, 2004). Discrimination and segregation, and crimes (Note 5) prevent an adequate harmonized economic planning in the county. With the environmental duality, planning does not seem to address the root issue of ethnic related-poverty in the impoverished neighborhoods. Severity of scarcity of resources in this neighborhoods is most likely to attract hedonic consumption and more crimes. The extensiveness and intensiveness of the crimes are likely to depend on the interactions between the substandard education and occupational skills, hedonic consumption, and the extent that racial discrimination and segregation dump citizens in the restricted and impoverished environments. Along with the inadequate applications to economic principles, these adverse and non-market factors tend to perpetuate the economic, educational, wage, and other inequalities, and African American in particular could not adequately apply themselves to the economic markets. Card and Dinardo (2002) present the source of wage inequality as emanating not only from technological competency, but also from non-market factors such as race, gender, and age implications.

\subsection{Introducing Economic Markets}

A market is a situation where there is an exchange of monetary payment (price) for a receipt of something scarce that has an economic value. American economy is based on market in the system of prices. The prices allocate economic resources among the competing functions. Economic goods and resources are rationed in some specific markets. Minority members, African Americans in particular, tend not to understand the U.S. price-based economy and therefore do not have adequate participation in it. Price is the amount of money that is paid or received in the process of purchasing and selling of economic goods or resources. Price takes different forms in the economic markets for product, labor, bonds, and money. Also known as price mechanism, the price system decides what, how, and when each good is produced. Due to an unawareness of the concept of price mechanism from the general context, some people tend to associate price only to product or service. This is the price that the non-market challenged in particular seem to be very much aware of. They tend not to understand that labor, bonds, and money have their respective prices in terms of wage rate, interest rate, and discount rate. We consume to derive some happiness (utility). The extra happiness that a purchaser of good expects from an extra consumption of the good or service is valued by the price that the purchaser is willing to pay. Also the extra amount that the seller earns by selling one extra good or service is valued by the price received. Understanding the role of the price system, would enable the economically disadvantaged to measure their consumption, the worth of their labor, and the return from financial instruments in the bonds market.

With implied indirect negotiations, both sellers and buyers of economic goods settle prices in the product markets. When both the buyers and the sellers of a particular goods or service agree to a particular price point, the product market will get to its equilibrium situation where the quantity that the buyers purchased is exactly the quantity that the sellers sold. Relating to this simple procedure of the functionality of the product market will guide the economically challenged to becoming market participants.

In the bonds market where borrowers acquire funds from lenders, the price paid for acquiring and for releasing funds takes the form of an interest rate. Non market participants may not understand interest rate as the price that is paid for borrowers to use the savers' funds. This particular price does not seem to be recognized just as the price of a product is recognized. Limited interactive engagements in this elitist market where interest rate is established tends to inhibit the understanding of the interest rate as a price. As in the product market, an agreement of the borrower and lender to a particular interest rate point leads to a market clearing or equilibrium condition where the quantity of funds borrowed is exactly the quantity lent. The understanding of this simple process of the bonds market's interactive adjustments could promote the desire of the economically challenged to engage the activities of this particular market.

In the labor market, price is the wage rate paid to the provider of labor by the receiver of the effort of the labor. As in other economic markets, a common wage point agreed to by both the provider and receiver of the effort of 
the labor will create the labor market equilibrium where the quantity of labor provided is exactly the same quantity of labor accepted by employers. As applicable to the product market, people tend to be familiar with the labor market that is usually known as the job market. Relating to this particular market will enable the poor to be familiar with the critical issues of wage rate that is expected to be equal to the value of the physical marginal product of labor. Also, increasing participation in this market will lead to increasing awareness of the issue of discrimination, by race and gender, of immigration, of child labor, of employment related benefits, and of fulltime and overtime hours.

Another economic market is the money market. This market involves the Federal Reserve Bank, Fed's ability to control the economy's money supply by changing the discount interest rate and by conducting open market operation. Open market operation involves the policy on the commercial bank's reserve requirements, and buying and selling of the U.S. securities. The discount rate decision which targets the short run control of money supply is also set in the open market operations. If there is a large quantity of money in the economy that will lead to inflation (rise in prices), the Fed will increase the discount rate which is the rate that commercial banks pay to loan money from the Fed. All the interest rates charged by banks, savings and loans, mutual funds, credit cards, retirements funds, and pawnshops are influenced by the discount rate. For example, an increase in the discount rate will lead to an increase in the federal funds rate which is the rate that banks pay to borrow the excesses of other banks. Also, an increase in the discount rate will reduce the ability of the commercial banks to acquire cheap loans from the Fed and the rates that the commercial banks charge their customers will therefore increase. A reduction of a discount rate would increase the money supply to have an expansionary economic effect.

\subsection{The Importance of Business Partnerships}

Business partnership is a market attribute that brings people with common or in some instances from diverged functional backgrounds to amalgamate the skills and funds required to underwrite the initial outlay of starting a business that seeks to achieve some reasonable level of economies of scale. Specialized talents and enhanced financial resources would lead to operational efficiency for lowering costs to therefore maximize profit. In order words, business partnership enhances the division and specialization of labor to achieve the economies of size that may not be realized where a single partner underwrites the operation. By contributing funds and other resources to have a viable partnership, those who would not have exercised market entrepreneurship would therefore be in the market. More entrepreneurs will therefore be raised. Business partnership is therefore a vital market attribute that is necessary to achieve a reasonable continuity in business (Samuelson \& Nordhaus, 2005, p. 119). Business partnerships in existing non-partnered businesses could enable the businesses to strive and to achieve business competitiveness and appreciable longevity. The benefits of comparative advantage could be enhanced where small initial venture capitals are merged to target some specific markets. If understood, business partnership could be the mechanism for alleviating ethnic minority-related poverty.

Businesses and professional partnerships are mostly in law, medicine, and technology, and are not common in petty businesses. Partnerships in small businesses are likely to engage the economic disadvantaged in buying and selling some goods and services. As the poor gathers market experience, their learning curve would most likely be an upward sloping curve. Poverty could diminish as the poor exercise market entrepreneurial activities. Not everyone may be active in some business partnerships. Some partners could be "sleeping partners". These partners, who understand the future value of money invested currently, could contribute funds or some resources or both to establish business or professional partnerships without being active in the day-to-day activities of the businesses. These kinds of partners could be seen as business financiers who expect to share from the profit of the partnered businesses. With limited involvement in the activities of the businesses, the sleeping partners could share from the profit in proportion to their contributions to the businesses. The active partners would expect earnings based on their contributions and for being active in the partnered businesses. The classification of partners as active or sleeping would depend on the charter of the partnerships. Financial institutions could partner with some groups of the economically disadvantaged with some concessionary micro loans to encourage the market participation of this group in the economic market that rewards greater than program incomes. Increased market participation of this group could diminish crimes and incarcerations. The poor, the less educated, and those with less market skills are mostly incarcerated (Georgia Department of Corrections, 2010).

Unfortunately, Dougherty County has not sufficiently realized the benefits of business partnerships as the few businesses that have partners reflect either Caucasian or Asian ethnicities. Even with the majority status of African Americans in the county, African American and White partnered businesses are not common, not even in the faith-based organizations. Even in the restricted economy of East Albany with African American majority, business partnerships are not visible among African Americans (Adams-Cooper, 2011). In this restricted area, 
black partnerships are visible mostly in nonprofit organizations and faith-based initiatives. In this same restricted economy, various business partnerships are common only among people of other races who understand the values of entrepreneurship and partnership. Generally, lack of partnership seems to emanate from distrust, from perceived disutility from interracial partnering, and from the fear of transferring wealth from one ethnic group to the other groups.

Trust is the denominator for forming enduring business partnerships. In order words, partnership rests on commonly accepted levels of integrity, honesty, and ethical behavior. An absence of a substantial trust from any member has the propensity to adversely affect both the earnings and the business reputation of other members. Unethical issues and violation of the laws can ruin a partnership. Community perceived ethical issues in any business could lead to avoidance of the business. To have a viable business, there must be a sufficient commitment in the different stages of business development. The commitment must be highly pronounced especially in the short run period of a business development when economic losses are possible due to the presence of a fixed cost — cost that must be paid even if production or service has not commenced. A hidden partner's agenda in a partnership is capable of causing some frictions among the members. Operational events reflecting a hidden agenda could drift a partnership from its mission.

The importance of trust in partnership is related to the principle of limited liability. The principle highlights that upon the failure of a partnered business, the partners can lose beyond what they invested in the business to pay creditors. They could lose their investment interest in other endeavors, their homes, and other personal belongings to pay creditors. Legally, upon the failure of the business, the richest partner or partners can assume the responsibility for the obligations of other partners that are financially unable to settle their respective obligations in the partnership. This situation compels the partners to demand the highest-level of trust from each and every partner.

An insinuation of business distrust and disagreement can be minimized with a formal document that provides a detailed expression on all the terms. Some level of self-interest must be compromised for the expected benefits of business partnership. Underwriting the initial capital outlay to have an efficient operation for maximizing profit ought to be important to all the partners. Participating partners need to understand why the current level of consumption is reduced in order to contribute to the optimal outlay to the partnership. Expected higher future levels of consumption relative to the current level must be an incentive to set up partnerships. Generally, partners share the earnings of the partnered business relative to their contributions in the business. Where there are both active and sleeping partners in the partnership, the partnership document must provide how the active members are to be compensated. The economically disadvantaged in Dougherty County could start off with some informal, small-scale partnerships to address some market niches.

\subsection{Financial Market}

A discussion on the benefits from participating in the financial market can be used to motivate the economically disadvantaged to exit from poverty. Given poverty, some people may not know about the existence of the financial market. Financial market is where the borrowers-spenders borrow money from the lenders-savers with bonds instruments. Issuing bonds instruments enable corporations, municipalities, cities, counties, and schools to raise money for development purposes. It is in the bonds market that the rate of interest (price of borrowing money) is established at the market equilibrium where the quantity demanded is equal to the quantity supplied of the bonds instruments. With reference to the Federal Reserve Bank discount rate, the established rate in the bonds market can decide the rates of interest that are expressed on small market instruments such as certificate of deposit (CD), savings accounts, and mutual funds. Also, bonds rates influence the rates that commercial banks charge their customers to borrow their loans. Banks' interest rate charges on credit cards, and pawn shops, payday and Check cashing rates are also influenced by the bonds rates.

Financial market provides an opportunity where lenders-savers earn extra incomes to augment the incomes from the labor market where the most aggregated income is earned. As the economically disadvantaged acquire market skills and principles, their participation in the financial market could substantially minimize economic inequalities. The economically disadvantaged should be led to realize that the reward from economic markets including the financial market substantially exceed the program incomes that if depended on for a long time, would perpetuate the disparities. Non market rewards may entice the economically disadvantaged since they are used to such rewards. With functional skills and market principles, the economically disadvantaged will understand the incentives for earning rewards from the markets. Expected high future market rewards and consumption must be shown to be positively correlated for the development of the contemporary skills and for engaging the market principles. This market reward challenge will highlight the desire of the economically 
disadvantaged to want to participate in the economic markets.

\subsection{Federal Reserve System and Commercial Banks Activities on the Economy}

The various interest rates in the commercial areas are related to the activities of the central bank of America popularly known as The Federal Reserve, Fed. The discount rate from the Fed influences the interest rates in our competitive economy. Just as bank customers pay some kinds of interest rates to borrow from the commercial banks, the commercial banks pay the discount rate to borrow a discount loan from the Fed. The Fed open market operation's policy on buying and selling of U. S. bonds influences the long run control of the money supply that in turn describes economic activities. With inadequate money supply, the Fed will expand the quantity of money in circulation by repurchasing the U. S. securities being held by the customers-purchasers of the bonds. As a result of the payout to the customers, the commercial banks would experience an increase in the amounts held in their vaults. Therefore, at the current or prevailing interest rate, the commercial banks are able to extend more loans to their customers. Entrepreneurs are therefore able to access more capital to expand the capacities of their business activities. Preventing the long term inflation would compel the Fed to encourage a tight monetary policy of selling U. S. bonds or securities. As a result of this policy, the short term discount rate could increase to encourage more investments in the U.S. bonds. An increase in this rate tends to increase the preference for investing in the U.S. secured or guaranteed bonds given that the U.S. government will not default on her instruments. The presentation of the various economic markets will encourage the economically challenged to have participations in them in order to earn the premium market incomes.

\subsection{Entrepreneurship}

Another market and income enhancement is the multiplier effect of entrepreneurship. Joseph Schumpeter recognized this effect that led him to characterize entrepreneurs as innovative market factor who organize capital and other resources to bring about economic development (Schumpeter, 1989). These creative risk takers are searchers of profit that are able to increase their incomes and those of others. Entrepreneurs are market innovators who take some calculated risks with the objective of maximizing profit. They analyze the possible options for dealing with market issues and then select the options that are deemed sufficient to address the market issues. They are able to engage marginal analysis procedure that weighs the marginal benefits against marginal costs (opportunity costs). Failure is possible in the markets but innovative entrepreneurs tend to persist in their search for profits. To have success, entrepreneurs will retry some other market options that are deemed feasible to engaging some other markets. Entrepreneurs engage market activities that would maximize profit from the appropriate scales of operations. The possible short-run losses due to the presence of the fixed cost may not deter the risk takers from targeting their expected planning horizon being the long run period. In this period, entrepreneurs would acquire more efficiency to diminish the average cost from their optimal plants or from the level of their operational activities.

Entrepreneurship relates to human capital that has both specific and general traits. Ucbasaran et al. (2008) presents that the specific traits characterize business, managerial, technical, and other special qualities. African American entrepreneurship is said to be highly limited due to inhibited specific market traits (Lofstron \& Bates, 2007). Limited African American market entrepreneurship tends to lead their preference for values from the political, non-profit, faith-based, and hedonic activities that are non-market activities. Ashenfelter (1978) presents that the acquired general human capital is influenced by factors such as education, job related experience, and trainings. Arrow (1985) presents both quantitative and qualitative education for describing a functional human capital. Limited education and capital are said to hinder African Americans from having ownerships in the hard to enter industries. Even in the easy to enter industries, African Americans are said to have the low entry and high exit rates (Lofstron \& Bates, 2007). Bearing on the work of Mr. Schumpeter and from the cited authors, every community needs entrepreneurs that self-select market norms to enhance their economic status and by so doing encourage others to earn market premium incomes. Market premium income is the difference between market income and the average program income from the same period. The difference would become a large positive value as more people self-select market activities instead of depending on income-supportive safeties of a welfare state.

The two kinds of entrepreneurship--specific and general seen not understood and are lacking most especially in African American community of Dougherty County. The specific entrepreneurship is the rare in-born type and could be hereditary. This is the special type of entrepreneurship that could develop early in the gifted people's lives. Parents could be the first to notice this specific type of entrepreneurship. This unique entrepreneurship could have a quick impact on economic development that could enhance the incomes and standard of living across the globe. The other kind of entrepreneurship is the general. This is the entrepreneurship that is acquired 
from education or from experiences. Generally, education enhances entrepreneurship but individuals' persistent learning and retraining will enhance the different levels of this entrepreneurship.

Schools and parents have the responsibility to reinforce the general entrepreneurship. Schools can encourage this innovation by providing effective, sufficient, and evolving curricula, savvy technology, and relevant internships. Mentoring can also reinforce the general entrepreneurship. Given the market constraints and rigidities, mentoring could focus on encouraging market innovators to create jobs and opportunities that will not only increase the innovators' incomes but the incomes of the others. Generally, African American majority neighborhoods do not have the entrepreneurship that evolved from the neighborhoods. Caucasian and people of Asian ancestry provide the limited entrepreneurship in these neighborhoods. These neighborhoods tend to duplicate faith-based initiative organizations, and businesses such as barbering and hair dressing salon shops whose scopes and scales of production are highly limited. With the limited entrepreneurship in the county, preference seems to be employment acceptances from the government, from faith-based organizations, and from the white minority establishments.

\subsection{The Role of Micro-Financing Institutions}

The economically challenged mostly could improve their market effectiveness with the presence of institutions such as micro financial institutions that specifically understand the plight of the poor. Relative to production and distribution, these institutions are on record for providing the moral, educational, and financial support to the economically challenged. As discussed in (Lui et al., 2006) communities, most especially the impoverished ones benefit from the presence of micro-financing opportunities. The opportunities could lead to financial shocks especially in the impoverished communities to effect reductions in poverty and in economic inequalities. The economy of Dougherty County has not financially accommodated a large number of the residents with low incomes. Particularly, the members of the African American community do not have an access to investment or production related capital. With the presence of many non-profit and faith-based organizations in the county, it seems they have more access to faith-based initiative loans than they do for commercial loans. Ethnic discrimination and segregation, limited education, and unavailability of collaterals seem to prevent the members of the ethnic African American majority in the county from capital formation.

Also, default from different levels of indebtedness that could arise mostly from consumer loans in a restrictive and impoverished environment such as Dougherty County could prevent a formation of production capital (Lardner \& Smith, 2005, p. 74). In this environment the capital formation terms on the contracts of the conventional financial outlets will most likely not be favorable. Bank request from customers of compensating balances can inhibit entrepreneurial goals. Lack of an understanding of the functionality of the financial market most especially by African Americans could lead to their loan denial.

The problem of unavailability of especially small scale loans could be addressed by the introduction of micro financing establishments in the county. These establishment have tractable evidences of emancipating the economically disadvantaged from poverty in South America and in Southeast Asian countries. Micro finance establishments have multiple instruments to address the diverse groups of the economically disadvantaged. These instruments that have diverse attributes can include micro credit, project financing, asset leasing, loans and advances, and deposit and savings. A particular instrument's attributes relate to a specific economically disadvantaged relative to the group's understanding of a particular economic market, ability to bear risks, and willingness to repay concessionary loans. An economically disadvantaged that understand the opportunity cost of the depositors of the loan-able funds and could articulate the functionality of a particular market, could benefit from the higher end of the financial instruments with more attributes than those at the lower end. Some combinations of the instruments could be used to trigger increasing market participation of those that demonstrate some appreciable propensities to succeed in the economic markets. Those that have not participated in the market in the past could be considered for any of the lower end financial instruments. They could be subjects for frequent assessments and monitoring of their credits. A favorable outcome from the assessment could lead to a recommendation for the award of higher end instruments as long as the beneficiaries have market participations and are repaying the respective financial obligations when due.

\subsection{Education, Skills, and Employment}

Education and market skills as a labor enhancement factors in the labor market are the most commonly accepted for reducing unemployment and economic disparities. These factors add value to human natural endowment and they have significant impact in explaining the average wage rates (equilibrium wage rates) in the labor market. They enhance the average physical product of labor that is the firm's efficiency parameter for determining the wage rates. Also, they can explain employment longevity, upward economic mobility, and the frequency of labor 
mobility among comparable jobs, among vertical employment levels, and geographically. With the proper education and skills, labor will specialize for diverse functions and the general education acquired enables the training and retraining of labor to enhance their productivity (Theodos \& Bednarzik, 2006, p. 43).

On the other hand, an uneducated labor would be expensive to train, to retrain, and also it faces the most employment shocks. Uneducated labor or unskilled labor and capital are substitutes in the production functions. This means that capital could easily replace labor when the price of labor becomes expensive or the price of capital becomes less expensive. Non-specialized labor does not command a reasonable comparative advantage in their respective employment. Hence the opportunity cost that is what is forgone for a particular employment could be comparable to the benefit from the employment. This assertion would imply that a non-specialized labor could be indifferent as to whether to remain in the respective current employment or to go back to the function that was given up. A situation like this does not lead to enhanced wage rates and other employment opportunities. Contrary to this situation, educated and specialized labor stands to enjoy substantial comparative advantages in their respective employment that are associated with the low opportunity costs.

Many studies support substantial returns to education in most circumstances. Generally, educated college graduates earns income that is about twice of the earning of an average high school graduate (Grubb, 1993; Welch, 1973; Hotchkiss, 1993; Theodos \& Bednarzik, 2006). High school graduates are most likely to have more difficulties than would the college graduates when searching for jobs and other opportunities. An educated college graduate will most likely invest in the financial market where extra incomes are earned to augment the labor incomes. Given the high school graduation and dropout rates of $57 \%, 44 \%$ (Note 6) respectively, it is apparent that the county has not yet achieved a qualitative education. The limited qualitative education in mostly East Albany that is predominantly African Americans leads to the commercialization of the respective economy by recent Asian immigrants and white people. In this same economy, African Americans tend to focus on achieving the most non-market values from political, social, and faith based activities. Theodos and Bednarzik (2006) and Gardner and Hern (1992) observe that qualitative education correlates with productivity and earnings and with market equity. A low educational endowment is associated with a low level of human capital that could be subjected to a non-market discriminatory low wage rates and upward work advancements. A higher proportion of black women than that of the white women as heads of households with limited education is said to explain the disparity of incomes between the two groups (Browne, 1997). D'Amico and Maxwell (1994) observe that the labor market incomes of both white and black youths are comparable where both have comparable high school educational preparations.

\section{Data and Methodology}

With a survey instrument on the critical market factors on: partnership, entrepreneurship, financial market, and some other market concepts, data is collected from among the student-body of Albany State University that is predominantly African American. Albany State University is a public institution and part of the Historically Black Colleges and Universities (HBCU). The University is a co-educational institution that is located in Dougherty County of Southwest Georgia where the southern poverty is highly pronounced. The students come from different socio- and economic- backgrounds that need some treatments with the market related principles to ignite their general and any latent specific (in-born) entrepreneurship possessed. College students are most likely to engage in experiential learning that could ignite especially, the educationally driven general entrepreneurship.

It needs to be mentioned again that Dougherty County that houses Albany State University has African America majority that observes very little business ownership. It looks as if the university does not have an appreciable impact on the economy of the county. Therefore, the students in this university would be the adequate testifiers of poverty and economic inequalities. Since poverty and economic inequalities are race-associated, market sampling from this kind of institution will enable the adequate assessment of the extent that economic market principles are understood. Without any concern as to what other students in a diversified student-body think; the sampled audience from this university, would without any inhibition provide the true market data. This data would be the true representative of the respective population for verifying and for elevating the discussion on race related poverty and inequalities.

In Dougherty County that houses the university, preference tends to be expressed for public and private employment, and for activities in faith-based organizations. In this situation, one would expect the sampled data to express a latent entrepreneurship in the county. The students that applied to the survey may have taken or are taking courses in the functional disciplines that are capable of driving up the general entrepreneurship mostly, for the application to the markets. An understanding on how much GPA is related to the market concepts is important to describing market success. Students could be going through college without having pragmatic 
understanding of the related activities. To cultivate an elevated market disciplines, students need to conceive the market principles and pragmatic activities right from college where knowledge induces the general entrepreneurship.

\subsection{Theoretical Models for the Economically Challenged Expected Incentive from the Market}

An understanding of the market norms and principles is expected to increase market participation, and earnings from the various economic markets. These market desirables will be necessary to diminish the long run poverty and economic inequalities, and dependence on the income safeties of a welfare state. Therefore, the earning (income) from the market that is above the relative program income will be a function of the extent to which the average would-be- market participant understands the enduring market concepts of: individualized economic markets (mkt), business partnership (buspa), and entrepreneurship (entrep). With formal education, these norms will describe a would-be-market participant. Awareness of the individualized markets would highlight the understanding of the various markets for: products, labor, bonds, and money that characterize the U.S. economy. This general market-income function can be stated as:

$$
\text { Market income } e_{t}=f(m k t, \text { buspa, entrep }) \text {. }
$$

Equation one implies that the impact of the exogenous factors will cause the expected improvement of income. Income is positively related to each of these predetermined factors. The idea and activities of partnership would encourage individual's comparative advantage and specialization that will lead to groups' adequate economies of scale and the associated lowest average cost of their operations. Market will reward the knowledgeable participants that understand the functionality of the various markets that make up our competitive market economy. These participants are most likely to understand and to simulate each market to find out what the expected rewards or incentives are.

Market risk premium-income model can also shed light on the income improvement of a market participant. Some market risks included in this model introduce the market participants to some challenges of operating in a competitive economy. With the understanding and willingness to take some basic market risks, the market's individual participant would be expressing more desire to explore market opportunities where the expected income exceeds the program income. The risk premium-income model basically demonstrates the premium income there is from the market activities instead of dependence on a program income. Application to market, not handout or program income would therefore tend toward reducing poverty and inequalities. Relative to the discussion in Mishkin 2001, given the challenges facing market participants, the risk premium income from embracing market factors is the amount by which the expected market income exceeds the program income and is expressed as:

$$
\text { Market Risk premium }=R E T^{e}-R E T_{f}=\beta\left(R E T_{m}^{e}-R E T_{f}\right)
$$

Where,

$\mathrm{RET}^{\mathrm{e}}=$ expected market income from all sources. This income underscores that the poor could attract some additional income on top of the dependent income

$\mathrm{RET}_{\mathrm{f}}=$ Risk-free dependent or program income

$\beta=$ Beta of the market

$\mathrm{RET}_{\mathrm{m}}^{\mathrm{e}}=$ Expected income from the market income.

The equation shows that the economically disadvantaged will be motivated to want to learn the market principles for participating in the economic markets where the market return is adjusted by the systematic risk (Note 7) described by beta. This adjusted return is substantially greater than the return from the program income. Where the economically disadvantaged learns and is able to apply to the various economic markets, the following equation shows the associated individual returns and risk parameters as:

$$
\begin{gathered}
\text { Risk premium }=R E T^{e}-R E T_{f}=\beta_{l}\left(R E T_{\text {factor } 1^{-}}^{e} R E T_{f}\right)+\beta_{2}\left(R E T_{\text {factor } 2}^{e}-R E T_{f}\right)+ \\
+. \ldots \ldots+\beta_{K}\left(R E T_{\text {factor } K}-R E T_{f}\right)
\end{gathered}
$$

This equation can be pragmatically explained to financially motive the economically disadvantaged.

\section{Research Findings and Results}

Six hundred and sixty survey responses on eight market-related questions were drawn from 110 students of the student body at Albany State University irrespective of gender and ethnicity. Questions one to six have the right and wrong answers and the right responses on them are used mostly to describe the students' would-be-market participations. Their understanding of the market requirements and activities could describe the extent that the 
market could diminish poverty and economic inequalities. Questions seven and eight do not have the right and wrong answers and the responses on them are characterized accordingly. The following Table 1 and Figure 1 highlight the distribution and percentages of the responses on the right options on the survey questions. The number of performance responses from each category is related to the number of the responses on the representative range of the grade point average, GPA (2.9-2.5).

Table 1. Market success performances

\begin{tabular}{cccc}
\hline Questions and Test & No. of Performances & \% of Performances & Ratio of Performances and GPA \\
\hline QI & 64 & 58 & 1.2 \\
Q2 & 72 & 65 & 1.4 \\
Q3 & 57 & 52 & 1.06 \\
Q4 & 89 & 81 & 1.68 \\
Q5 & 98 & 89 & 1.85 \\
Q6 & 30 & 27 & 0.57 \\
N=110 & & & \\
responses on each question and 660 & & & \\
responses on all the questions & & & \\
\hline
\end{tabular}

Key on the Questions (Qs): Q1=Knowledge of different prices-price of product, wage rate, and interest rate, Q2=Knowledge of business partnership, Q3=Knowledge of financial market, Q4=Knowledge of entrepreneurship, Q5=Knowledge of maximizing business profit relative to cost and output, Q6= Knowledge of competitive product market. Q7 gathers information on Grade Point Average, and Q8 gathers information on African American Market Inhibitors.

The concept of price mechanism as allocator of resources in a competitive economy such as the U.S. has not been understood by a lot of the students. On the question addressing the recognition of competitive pricing in the different economic markets, only $58 \%$ of the surveyed students understands the role of the competitive pricing for allocating goods and services, labor services, and bonds in their respective markets. Thirty-eight percent of the responses sees competitive pricing only in the product market. This percentage is not surprising given that everyone goes to the product market to purchase goods and services. Only $0.07 \%$ of the responses shows the understanding of a competitive wage rate as a price in the labor market.

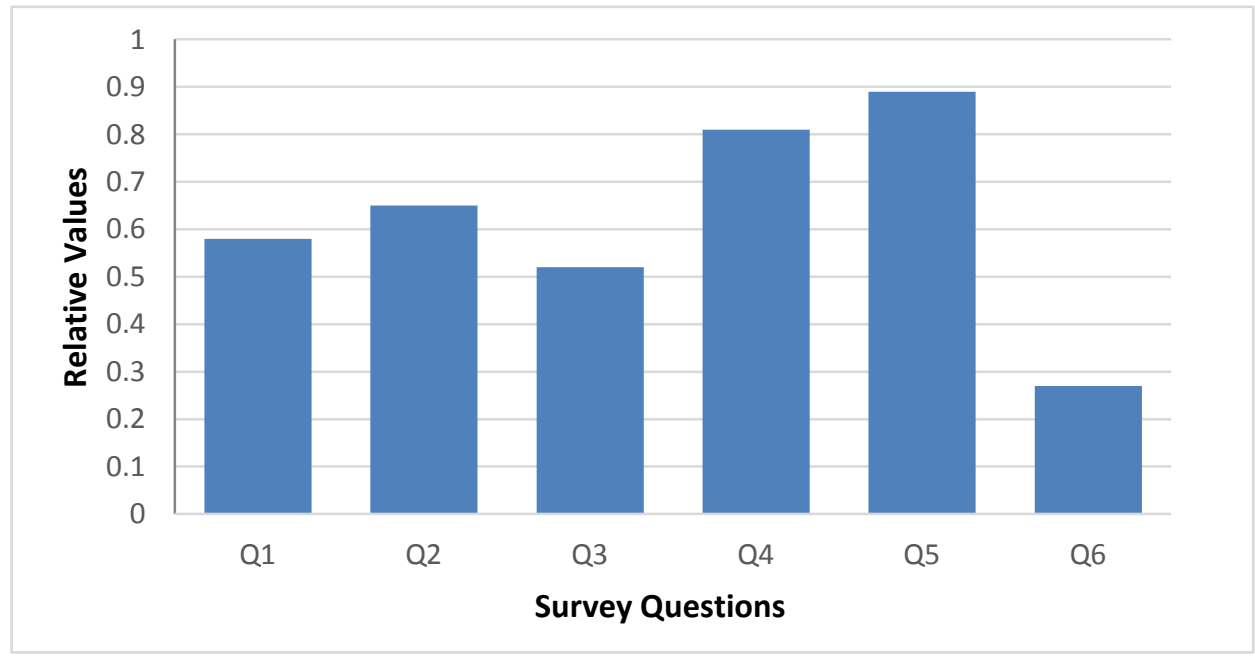

Figure 1. Survey of performance responses

Students need to reinforce their understanding of the importance of business partnerships as a way of amalgamating funds and other resources to underwrite the initial business outlays that are beyond the capability of an individual. Partnership provides a novel avenue to be competitive in small businesses that are expected to survive the short run losses, and for planning for the long run. On the respective question, only $65 \%$ of the student responses implies the students' market awareness of the critical role of partnership as a market factor. 
This factor could lead to initial entry into the market and if one is struggling in the market, it could lead to diminished average total cost of operation due to the realization of an appropriate economies of scale. Roughly $34 \%$ of the responses implies unawareness of the critical role of partnership. Lack of business trust could be inhibiting the knowledge of this factor. By submitting to a legally drafted article on partnership, the members could substantially minimized the mistrust. If applicable, the mistrust could be further reduced by having very few active members to conduct the day to day operations while the silent or "sleeping members" participate only when called. With this arrangement, the active members get compensated for operating the business in addition to their compensation from the profit.

Students could be getting small loans from small financial companies without the basic idea of why individuals participate in the financial market. On the understanding of the basic knowledge for participating in this market, the percentage of the student performance responses is unacceptable. Only $52 \%$ of the responses has the common core knowledge that individuals participate in the financial market to lend and to borrow with the applicable instruments. A low percentage such as this could imply that the students are basically acquiring education only for the purpose of getting jobs. They tend not to understand the benefits of being in the financial market. Forty-three percent of the responses implies lack of the knowledgeability of this important market where extra incomes could be earned to augment the popular labor market incomes.

Students may have had entrepreneurship classes to be able to highlight the entrepreneurship factor. Generally, the level of assessment performance responses on the importance of entrepreneurship is acceptable given the associated $81 \%$ rate of the responses. Roughly, $19 \%$ of the responses would imply lack of understanding of the activities of entrepreneurship. While the rate of the knowledgeability of entrepreneurship portrays a general awareness of the activities of the market entrepreneurs, the specifics on how to observe the entrepreneurship factor need to be explored. Increasing awareness of the specifics on the factor could come from the understanding of the competitiveness of the markets and by engaging the concepts of: marginal analysis, comparative advantage and specialization, and global trade to analyze economic opportunities. Along with the understanding of the importance of market partnership, engaging these concepts and accessing functional capital, would determine whether market risk taking is worthwhile.

Articulation of profit and profit earning procedure is encouraging. On the respective question, roughly $90 \%$ of the responses encourages production according to a business' share of the market. The responses suggest that over production and underproduction will lead to producing at a high cost. Cost minimization is necessary to produce the efficiency output that would enable profits to be maximized according to the market competitiveness driven by the market structure. An understanding of the concept of marginal analysis will enable production and price to be pegged at the point where the marginal revenue is equal to marginal cost. Below this production point, increasing production would decrease the cost of production. And beyond this point increasing production would increase the cost of production.

Students have not understood the concept of competitive pricing in a competitive product market. Only $27 \%$ of the performance responses implies the understanding of pricing according to the competitiveness of the market. Seventy-two percent of the respondents do not understand competitive pricing. The respondents could be charging wrong prices by not knowing the competitiveness of the market they are in. It is imperative for market participants to realize that in competitive environments that each producer will charge relative to the price charged by the other producers of the comparable goods. A price below the going price could amount to the price going below the average cost and the respective producer will incur an economic loss. Also, an increase of the going price by even a penny will lead to an entire loss of sales.

Most responses on the GPA fall within the GPA range of 2.9-2.5 with a response rate of 48\%. The GPA responses within the range of 3.5-3.0 constitute a response rate of 37\%. With response rates of $10 \%$ and $4.5 \%$, the responses fall within the GPA ranges of 3.6 and up, and 2.4-2.0 respectively. Cautiously speaking, these statistics would support that the students have limited understanding of the market factors. Also, they are highlighting the students' passiveness in college where they are supposed to be drawing meaningful market experiences. There must be leads and encouragements for the students to engage the markets pragmatically to achieve the most expected earnings, given the competitiveness of the markets.

Among other compelling factors, a limited education is mostly blamed for the limitedness of African Americans participation in the economic markets with a response rate of $36 \%$. This is not surprising given a very low student academic achievements from the public school systems. Students may not be well prepared for college success. Students may not be caring enough about the importance of education as an income equalizer. They could be exercising the minimum effort in their pursuit of educational success and would apply to the jobs that 
do not require education if unsuccessful. To counteract these adversities at the college level, the activities of the institutional factors may need to be enhanced to encourage college related effort (Nwaokoro, 2010).

With a response rate of $30 \%$, a lack of interest in taking risks is the second factor that is blamed for the inactive African American market participation. This is not surprising given that the respondents' cultural, economic, and entrepreneurial backgrounds are yet to reflect strong market requirements. Along with the functional business education, market simulation and workshops, application to pragmatic market activities and to business internships could assist to reducing the market inhibitors. Though discrimination and segregated environments as a factor prevents African Americans' market participation, its impact weighs minimally. Seventeen percent of the responses blames discrimination and segregated environments as being responsible for the inability of the African Americans to participate in the economic market. This low percentage would imply that the society is becoming fairer. The students may not have enough experiences to characterize discrimination and segregated environments.

Sixteen percent of the responses implies that lack of access to capital is the obstacle preventing African Americans' market participation. The responses on the access to capital may reflect the respondents' family experiences since college students are unlikely to ask for access to capital. This factor may not be considered as a strong market inhibitor because the respondents may not know what to do with capital in a market environment, where the White owned businesses have explored most of the benefits of economies of scale. Again this low percentage could be implying that the society is becoming fairer. In a nutshell, among other compelling actions, the responses provided on the survey highlight the need for effective education, increasing interest in taking market risks, elevation of access to capital, and a fairer society.

As expected most responses on the grade point average fall within the range of 2.9-2.5. To have some clue as to how the effect of education could improve market awareness, the number of the responses on this range is related to the number of the responses on each correct option of each question. The respective quotients from this relationship are posted in column four of the Table 1. For example, with a unit point improvement in the GPA, the understanding of the different prices of question 1, will improve by 2.1 points. With this estimate, one could cautiously say that education has impact in the awareness of market factors.

\section{Conclusion and Future Study}

Dougherty County is characterized by poverty, remoteness, and substantially low academic achievements from the public school system, discrimination and segregation, and the exit of white and rich African Americans from the county. With these adversities, there is a market failure in directing economic outcomes. To measure the awareness of the specific market principles, this study sampled college students' knowledge of the different prices in a competitive economy, of the importance of business partnership, of financial market, of entrepreneurship, of profit motive, and of competitive product market. College students are more likely to exercise the educationally induced market entrepreneurship to alleviate the economic adversities in the county. College education could even lead to a discovery of the latent specific human capital of the naturally gifted individuals that could foster economic development.

The general performance of the students from the survey is mixed and not encouraging. This is to say that most of the market principles are not articulated by the respondents. Specifically, they tend to have a bit of understanding of the principles of entrepreneurship and of the profit motive. More awareness of these fine principles is highly desirable for individuals to tie entrepreneurship with the incentive of profit rewards. Introductory courses in economics and entrepreneurship, if taught on pragmatic basis can highlight these awareness. Students need be asked to recognize the key words, concepts, and issues of significance from these courses and could be asked to apply to assignments that demands constructing market related narratives with the terms.

There is a performance failure in the recognition of the importance of competitive prices (wage, interest rate, and composite price of the goods and services), of business partnership, of the financial market, and of the competitive product market. Improvements on these principles could come from the introductory courses in economics, business, finance, and marketing. Improving GPA is expected to elevate market awareness. Future study on market awareness may have to focus on how quantitative courses could be interestingly taught to students. It is very important for students to enhance their aptitude on ratio and marginal analysis to empirically compare and contrast values - comparing apples to apples, and contrasting apples with oranges.

\section{References}

Adams-Cooper, V. (2010). Addressing the Roots of Black Poverty in the United States: A Proposed Dual 
Macro-Micro, Niche-Market Network Systems Approach [White Paper]. Albany, GA: VAAC Consulting Inc.

Ahmed, S. M., Mushtaque, C., \& Abbas, B. (2001). Micro-Credit and Emotional Well-Being: Experience of Poor Rural Women from Matlab, Bangladesh. World Development, 29(11), 1957-1966. https://doi.org/10.1016/S0305-750X(01)00069-9

Arrow, K. J. (1985). The theory of discrimination. Applied Economics, 6. Belknap Press of Harvard University Press, Cambridge, Massachusetts.

Ashenfelter, O. (1978). Estimating the effect of training program on earnings. The Review of Economics and Statistics, 60(1), 47-57. https://doi.org/10.2307/1924332

Bagi, S. (2008). An Analysis of Inequality, Human Development, and Economic Growth. Southwestern Journal of Economics, $x(2), 69-80$.

Browne, I. (1997). Explaining the Black-White Gap in Labor Force Participation Among Women Heading Households. American Sociological Review, (62), 236-252. https://doi.org/10.2307/2657302

Card \& Dinardo. (2002). Skill-Based Technological Change and Rising Wage Inequality: Some Problem and Puzzles. Journal of Labor Economics, 20(4), 733-783. https://doi.org/10.1086/342055

D’Amico, R., \& Nan, L. M. (1994). The Impact of Post-School Joblessness on Male Black Wage Differentials. Industrial Relations, 184-205. https://doi.org/10.1111/j.1468-232x.1994.tb00335.x

Dougherty County School System. (2002-2009). DCSS Graduation \& Dropout Rates. Dougherty County School System. Albany, Georgia.

Farr, J. L., \& Sibyl, S. S. (2008). Albany, Georgia: the East Albany Neighborhood. Federal Reserve Bank Working Paper, Albany Georgia.

Garder, J. M., \& Diane, E. H. (1992). Working and Poor in 1990. Monthly Labor Review, 20-28.

Georgia Bureau of Corrections. (2010). Reports: Annual Statistics. Georgia Department of Corrections, Atlanta, Georgia.

Georgia Department of Labor. (2010). 1990-2009 Unemployment rate: Workforce Professionals: Historical Data. Georgia Department of Labor, Atlanta, Georgia.

Grubb, N. W. (1993). The varied economic returns to postsecondary education: New evidence from the class of 1972. Journal Human Resources, XXVIII(2), 365-381. https://doi.org/10.2307/146208

Hotchkiss, L. (1993). Effects of training, occupation, and training-occupation match on wage. Journal Human Resources, 28(3), 482-496. https://doi.org/10.2307/146156

Hoynes, H. W. et al. (2006). Poverty in America: Trends and Explanations. Journal of Economic Perspectives, 47-68. https://doi.org/10.1257/089533006776526102

Khandker, S. R. (2005). Microfinance and Poverty: Evidence Using Panel Data from Bangladesh. The World Bank Economic Review Advance Access, 19(2), 263-286. https://doi.org/10.1093/wber/lhi008

Lardner, J., \& Smith, D. A. (2005). Inequality matters: The growing economic divide in America and its poisonous consequences. New York, NY: New Press.

Lofstron, M., \& Bates, T. (2007). African Americans' pursuit of self-employment. Discussion Paper Series (Discussion Paper No. 3156). Institute for the Study of Labor. Bonn, Germany.

Lui, M., Robles, B., Leondar-Wright, B., Brewer, R., \& Adamson, R. (2006). The color of wealth. New York, NY: New York Press.

Mishkin, F. (2001). The Economics of Money, Banking, and Financial Markets (6th ed.). Addison Wesley, New York, USA.

Morduch, J. (2002). Analysis of the Effects of Microfinance on Poverty Reduction (pp. 1-163). NYU Wagner Working Paper. Robert F. Wagner Graduate School of Public Service, New York University.

Nwaokoro, A. N. (2010). An Investigation of Institutional Enhancement Factors on Student College Success. Contemporary Issues In Education Research, 3, 1-7. https://doi.org/10.19030/cier.v3i8.221

Riddell et al. (2011). Economics: A Tool for Critically Understanding Society. Pearson/Addison Wesley, San Francisco, California. 
Samuelson, P. A., \& William, D. N. (1998). Economics 6e. McGraw-Hill/Irwin, New York.

Schiller, B. (2008). The Economics of Poverty and Discrimination. Pearson: Prentice Hall. Upper Saddle River, N.J.

Schmitt, J. (2004). The Rise in Job Displacement, 1991-2004. Challenge, 46-68.

Schumpter, J. A. (1989). Essays: On entrepreneurs, innovations, business cycles, and the evolution of capitalism. New Brunswick, NJ: Transaction Publishers.

Selig Center for Economic Growth. (2009). The multicultural economy. Terry College of Business, University of Georgia. Athens, Georgia.

Servon, L., \& Timothy, B. (1998). Microenterprise As An Exit Route from Poverty: Recommendations for Program and Policy Makers. Center for Economic Studies, Washington Plaza II, Room 211, Bureau of the Census, Washington, DC. https://doi.org/10.1111/j.1467-9906.1998.tb00430.x

Theodos, B., \& Robert, B. (2006). Earnings Mobility and low-wage workers in the United States. Monthly Labor Review, 34, 34-47.

Ucbasaran, D., Paul, W., \& Mike, W. (2008). Opportunity Identification and Pursuit: Does an Entrepreneur's Human Capital Matter? Small Business Economics, 30, 153-173. https://doi.org/10.1007/s11187-006-9020-3

Welch, F. (1973). Black-White Differences in Return to Schooling. The American Economic Review, 63(5), 893-907.

\section{Notes}

Note 1. The population percentage estimates are retrieved from: http://www.city-data.com/county/DoughertyCounty-GA.htm1, while the population estimate is retrieved from: http://www.city-data/county/DaughertyCounty-GA.html;http://dougertycounty.georgia.gov/03/home/0,2230,846 6851,00.htm1

Note 2. The south that has one-third of the U.S. population has $40 \%$ the U.S. poor (Riddell et al., 2011, p. 269).

Note 3.This estimate is calculated from the purchasing power data of The University of Georgia, Terry college of Business, Selig Center for Economic Growth.

Note 4. High school graduation and dropout rates of $57 \%$, and $44 \%$ respectively, and unemployment rate that rose from $7.4 \%$ in the early 1990 s to 10.2 by 2009 characterize the county.

Note 5. The crimes indexes are accessible at: http://services.georgia.gov/gbi/crimestats/viewCrimeStatReport.do From 2000 and 2010, the various crimes in the county included vehicle theft, larceny, burglary, assault, robbery, rape, and murder.

Note 6. Dougherty County School System provided these estimates.

Note 7. Systematic risk is measured by beta-measures the behavior (sensitivity) of an instrument's return to the changes in the market portfolio of instrument as

$$
\beta=\frac{\% \Delta \text { in instrument's value }}{\% \Delta \text { sin market portfolio of instrument }}
$$

If the change in asset's value is less than the change in the market portfolio of instruments, the systematic risk is low. Any asset with a high beta is associated with high systematic risk, and is less desirable in the portfolio of assets and therefore should have a high market risk premium.

\section{Copyrights}

Copyright for this article is retained by the author(s), with first publication rights granted to the journal.

This is an open-access article distributed under the terms and conditions of the Creative Commons Attribution license (http://creativecommons.org/licenses/by/4.0/). 